\title{
The Effects of Corporate Governance on the Performance of Manufacturing Sector Companies on the Indonesia and Philippines Stock Exchanges
}

\author{
Liliana Inggrit Wijaya ${ }^{1 *}$, Arif Herlambang ${ }^{2}, \&$ Willi Brodus The Mone ${ }^{3}$ \\ ${ }^{1}$ University of Surabaya, Surabaya, Indonesia \\ ${ }^{2}$ University of Surabaya, Surabaya, Indonesia \\ ${ }^{3}$ University of Surabaya, Surabaya, Indonesia \\ ${ }^{*}$ Corresponding author. Email: liliana@staff.ubaya.ac.id
}

\begin{abstract}
This study aims to examine the effects of corporate governance on the performance of manufacturing sector companies listed on the Indonesia and Philippines Stock Exchanges over the 20152019 period. This research uses a quantitative approach with a multiple linear regression method. The object used in this research was 455 observation data on Indonesia Stock Exchange and 170 observation data on the Philippines Stock Exchange. The dependent variables in this study are ROA which represents accounting-based, and Tobin's Q, which represents market-based. Then, the independent variables in this study are board size, board meetings, institutional ownership, while the control variables are leverage and firm size. The results showed that board size has no significant effect on ROA in Indonesia and the Philippines but negatively affects Tobin's $\mathrm{Q}$ in Indonesia and the Philippines. The board meeting negatively affects ROA in Indonesia and positively affects ROA in the Philippines. But board meeting also has no significant effect to Tobin's Q in both Indonesia and Philippines. Institutional ownership has no significant effect on ROA in Indonesia and positively affects Tobin's Q in Indonesia. But institutional ownership also has a significant negative effect on ROA and Tobin's Q in Filipina. Whereas in the control variables, leverage negatively affects ROA and Tobin's Q in Indonesia and the Philippines. Firm size has a significant positive effect on ROA in Indonesia and the Philippines and has a significant negative effect on Tobin's Q in Indonesia. Firm size also has no significant effect on Tobin's Q in the Philippines.
\end{abstract}

Keywords: Board Size, Board Meetings, Institutional Ownership, Firm Performance.

\section{INTRODUCTION}

The relationship between corporate governance and firm performance has become a hot topic to study by researchers in developed countries. In recent years, this issue is also discussed in developing countries due to the corporate collapse and fraud modes. The company collapsed due to a weak corporate governance system; thereby, they need to improve and reform their governance structure.
Good corporate governance may contribute to accounting fraud, and companies with weak governance structures are more vulnerable to accounting fraud (Berkman et al., 2009 in Arora and Sharma, 2016). The failure to prevent fraud sparks much debate about the effectiveness of the current corporate governance regulations, principles, structures, and mechanisms (Sun et al., 2011 in Arora and Sharma, 2016).

Good corporate governance also refers to a set of rules and incentives where company 
management is directed and controlled (Velnamphy, 2013 in Muchtar and Darari, 2013). Agency problem theory stipulates that a company director will be more careful in managing his own money than other people's money (Letza et al., 2004 in Arora and Sharma, 2016). This theory also states that the primary goal of good corporate governance is to assure shareholders that managers work to achieve the results desired by shareholders (Shleifer and Vishny, 1997 in Arora and Sharma, 2016).

Arora and Sharma (2016), who study "The effects of good corporate governance on firm performance use the dependent variables of return on assets (ROA), return on equity (ROE), Tobin's Q, net profit margin (NPM), and stock return (SR). While the independent variables used are square of board size (BS), square of board meetings (BM), square of a proportion of outsider directors (PO), CEO duality (CEO dual), and institutional ownership (IO) by considering firm age, leverage, firm size, advertising intensity (AdvInt), and research \& development intensity (RDInt) as the control variables. This study shows that the effects of BM and IO on firm performance measured by ROA, ROE, and SR are insignificant positive. They have a significant negative effect on NPM and a significant positive effect on Tobin's Q. CEO dual has an insignificant negative effect on ROA, ROE, and SR. However, CEO dual has an insignificant positive on NPM and Tobin's Q. PO has an insignificant positive effect on ROA and ROE has an insignificant negative effect on NPM and SR. A significant negative on Tobin's Q. BS has an insignificant negative effect on ROE and SR, a significant negative effect on ROA, an insignificant positive effect on NPM, and a significant positive effect on Tobin's Q.

In the control variables, leverage has an insignificant negative effect on ROE, Tobin's Q, and SR, but has a significant negative effect on ROA and NPM. Meanwhile, size has an insignificant negative effect on ROA and Tobin's Q, a significant positive effect on NPM and SR, and an insignificant positive effect on ROE.

Malik and Makdoom (2016) who also study "The effects of good corporate governance on firm performance use the dependent variables: ROA, Tobin's Q, and SR. Meanwhile, the independent variables used are board size (BS), board independence (BI), board meetings (BM), large shareholders (LS), and CEO compensation (CC) which also considering firm size and leverage as the control variables. The results of this study reveal that BS has a significant negative effect on ROA, Tobin's Q, and SR. BM has an insignificant negative effect on ROA and SR, but has a significant positive effect on Tobin's Q. Then BI has a significant positive effect on ROA, Tobin's Q, and SR. LS has an insignificant positive effect on ROA, Tobin's Q, and SR. Meanwhile, CC has a significant negative effect on ROA and Tobin's Q, but has an insignificant negative effect on SR.

Haji dan Mubaraq (2015) who study the same topic, use the dependent variables: ROA, ROE, and Tobin's Q. The independent variables used in this study are board size (BS), board meetings (BM), independence director (INDs), family members on board (FMB), position of the chairperson (INDCP), director ownership (DIROWN), government ownership (GO) and institutional ownership (IO). The results of this study reveal that BS, $\mathrm{BM}$, and IO have a significant negative effect on ROA and Tobin's Q, but BM has an insignificant positive effect on ROE. BS has an insignificant negative effect on ROE. INDs have a significant negative effect on ROA, an insignificant positive effect on ROE, and an insignificant negative on Tobin's Q.

Then FMB has a significant negative effect on ROA and Tobin's Q, an insignificant positive effect on ROE, and INDCP has a significant positive effect on ROA, ROE and Tobin's Q. DIROWN has an insignificant positive effect on ROA, a significant negative effect on $\mathrm{ROE}$, and an insignificant negative effect on Tobin's Q. Meanwhile, GOVOWN has a significant negative effect on ROA and ROE, but an insignificant negative effect on Tobin's Q. Firm size, which is the control variable of this study, has a significant positive effect on ROA and Tobin's Q but has an insignificant positive effect on ROE. Meanwhile, the sec- 
ond control variable, leverage, has a negative significant negative effect on ROA and ROE and an insignificant negative effect on Tobin's Q.

\subsection{Literature Review}

This study is different from previous research. It discusses the effects of good corporate governance on manufacturing companies' performance listed on the Composite Stock Price Index (IHSG), representing the Indonesia Stock Exchange compared to the manufacturing companies listed on the Philippines Stock Exchange (PSE).

The manufacturing sector is chosen because it contributes the second largest number of companies in the Top 50 Companies according to the Indonesian Institute for Corporate Directorship (IICD). While the Philippine Stock Exchange was chosen because, according to the 2018 Asian Corporate Governance Association (ACGA), the Philippines has a CG score almost similar to the Indonesian CG score.

According to Klein (1998), a larger number of commissioners leads the firm's management to be more effective in adapting to the complexities of the business environment and organizational culture. In addition, a larger number of commissioners can gather more information; thus, the number of commissioners seems to be better for firm performance. A larger board of directors can also reduce individual weaknesses through collective decision-making.

H1: Board size has a positive effect on firm performance.

According to Arora \& Sharma (2016), the number of board meetings has a significant positive effect on firm performance. When the board of commissioners meets frequently, they tend to discuss problems faced by the firm, find solutions, and carry out their duties according to the shareholders' wishes. Thereby, more frequent board meetings are needed to improve firm performance. In addition, commissioners who have more time to discuss tend to make better decisions in response to crises because time constraints are seen as a major barrier to a more active monitoring by the board of commissioners.

$\mathrm{H}$ 2: Board meetings have a positive effect on firm performance.

According to Lee (2009), firms with greater institutional ownership will perform better because institutional investors have the resources and the ability to monitor management decisions well.

H3: Institutional ownership has a positive effect on firm performance.

\section{RESEARCH METHODS}

This study is basic research because it intends to develop research that has been done previously. When viewed from various basic research types, this study is causal research, which examines the effects of the independent variables: board size, board meetings, and institutional ownership and the control variables: firm size and leverage on the dependent variables: ROA and Tobin's Q in manufacturing companies listed on the Indonesia and Philippines Stock Exchanges over the 20152019 period. This study used secondary data in the form of financial reports of all manufacturing companies listed on the Indonesia and Philippines Stock Exchanges over the 2015-2019 period. The dependent variables used in this study were ROA and Tobin's Q. The independent variables used were board size, board meetings, institutional ownership, and control variables: firm size and leverage. This study applied one equation as follows:

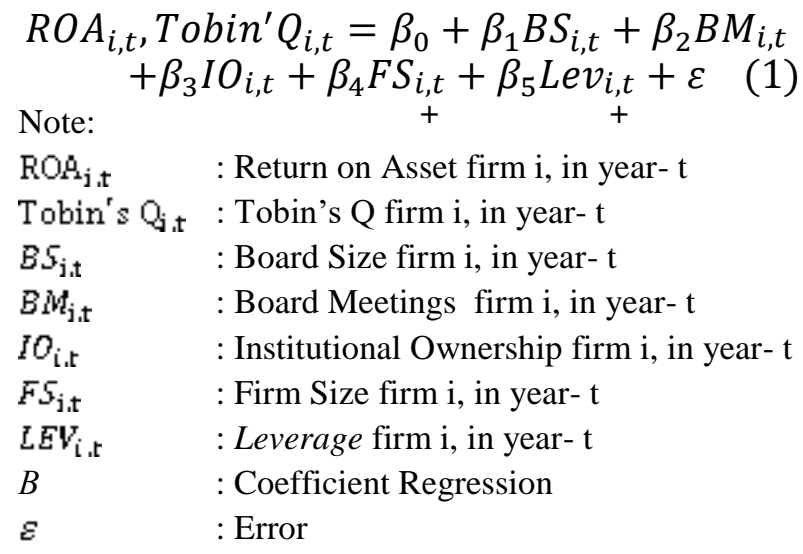




\section{RESULTS AND DISCUSSIONS}

This study uses a sample of manufacturing companies listed on the Indonesia and Philippines Stock Exchanges over the 2015-2019 period. The final sample consists of $455 \mathrm{ob}-$ servational data for the Indonesian sample and 170 observation data for the Philippines sample. Regressions result are shown in the table bellow

Table 1. Regression Results: ROA Indonesia

\begin{tabular}{lll}
\hline $\begin{array}{l}\text { Independent } \\
\text { Variable }\end{array}$ & Coefficient & Probability \\
\hline BS & -0.001445 & 0.2301 \\
BM & -0.000948 & $0.0216^{* *}$ \\
IO & 0.007080 & 0.1761 \\
Control & & \\
Variable & & \\
LEV & -0.131831 & $0.0000^{* * *}$ \\
FS & 0.034787 & $0.0000^{* * *}$ \\
\hline
\end{tabular}

Table 2. Regression Results: Tobin's Q Indonesia

\begin{tabular}{lll}
\hline $\begin{array}{l}\text { Independent } \\
\text { Variable }\end{array}$ & Coefficient & Probability \\
\hline BS & -0.019456 & $0.0000^{* * *}$ \\
BM & 0.000782 & 0.6639 \\
IO & 0.080944 & $0.0059^{* * *}$ \\
Control & & \\
Variable & & \\
LEV & -0.518239 & $0.0000^{* * *}$ \\
FS & -0.050347 & $0.0038^{* * *}$ \\
\hline
\end{tabular}

Table 3. Regression Result: ROA Filipina

\begin{tabular}{lll}
\hline $\begin{array}{l}\text { Independent } \\
\text { Variable }\end{array}$ & Coefficient & Probability \\
\hline BS & -0.000433 & 0.6047 \\
BM & 0.004727 & $0.0000^{* * *}$ \\
IO & -0.071660 & $0.0059^{* * *}$ \\
Control Var- & & \\
iable & & \\
LEV & -0.170396 & $0.0000^{* * *}$ \\
FS & 0.023430 & $0.0000^{* * *}$ \\
\hline
\end{tabular}

Table 4. Regression Results: Tobin's Q Philippines

\begin{tabular}{lll}
\hline $\begin{array}{l}\text { Independent } \\
\text { Variable }\end{array}$ & Coefficient & Probability \\
\hline BS & -0.069041 & $0.0864^{*}$ \\
BM & 0.023935 & 0.3161 \\
IO & -2.288162 & $0.0010^{* * *}$ \\
Control Var- & & \\
iable & & \\
LEV & -0.590490 & $0.0616^{*}$ \\
FS & -0.068730 & 0.1947 \\
\hline
\end{tabular}

Based on Tables 1 and 3, the board size (BS) has an insignificant effect on firm performance based on ROA in Indonesia and the Philippines. This result indicates that the number of BS does not affect firm performance based on ROA. The number of BS in carrying out its supervisory function does not have a major effect on managerial decisions in determining firm policy. The firm needs a board of commissioners with competence in finance/accounting and has business experience more than a large number of commissioners. In other words, board size does not determine the company profits (Ratnadi and Ulupui, 2016).

However, Tables 2 and 4 show that BS has a significant negative effect on firm performance based on Tobin's Q in Indonesia and the Philippines. This result indicates that the more the BS, the worse the firm performance based on Tobin's Q. This is because more BS will weaken communication among the boards and make the coordination difficult, thus challenging to make effective decisions. Therefore, the decision used is often the most vote that does not necessarily have a good effect on firm performance, which can cause investors to feel pessimistic about the firm (Malik and Makdoom (2016)). These results are supported by the fact that both Indonesia and the Philippines apply a system that separates the board into directors and commissioners.

Based on Table 1, the board meeting (BM) has a significant negative effect on firm performance based on ROA in Indonesia. This result indicates that the more the $\mathrm{BS}$, the worse the firm performance based on ROA. This is due to the high costs that must be incurred to organize the meeting. Costs incurred can be in the form of wasted time spent by members of the board of commissioners which can actually be used for doing other important tasks, travel costs, and other costs that must be spent in organizing the meeting.

Table 3 shows that $\mathrm{BM}$ has a significant positive effect on firm performance based on ROA in the Philippines. This result is in line with the proposed hypothesis, where the more the BM, the better the firm performance based on ROA because BM allows the board of 
commissioners to monitor and implement company strategy effectively. As such, more frequent meetings will increase the role of the board of commissioners in controlling managers and other benefits that have a positive effect on firm performance. This is supported by the level of discipline 59.6 or above the mean by the board of commissioners in the Philippines to carry out its functions in the form of board of commissioners' meetings. Then, in Tables 2 and 4, it can be seen that $\mathrm{BM}$ has an insignificant effect on firm performance based on Tobin's Q in Indonesia and the Philippines. This result indicates that the number of BM has no effect on firm performance. However, this can be explained by routine board meetings, which allow the board of commissioners to have more time to negotiate, define strategies, and assess managerial performance. Thus, this will help the board of commissioners to stay informed and knowledgeable about important firm problems.

Table 1 exhibits that institutional ownership (IO) has an insignificant effect on firm performance based on ROA in Indonesia. This result indicates that the amount of IO does not affect firm performance based on ROA. However, firms with large IO are recognized to perform better because institutional investors have the resources and ability to monitor management decisions properly. Institutional investors also provide input to management in managing the firm, but it seems that these inputs do not affect firm performance improvement. Share ownership that is concentrated in the institution offers better control to monitor management actions actively and prevent management's opportunistic behavior for its personal goals. Table 2 shows that IO has a significant positive effect on firm performance based on Tobin's Q in Indonesia. This result is in line with the proposed hypothesis, where the greater the IO, the better the firm performance based on Tobin's Q. With large institutional ownership, the level of control exercised by the external party of the company will be stronger. Firms with institutional ownership related to the business family have a good performance. Their existence prevents the occurrence of perquisites by company management which can cause agency costs. The fact that most institutional investors in Indonesia have close relationships with their firms. In addition, the amount of institutional ownership is a signal for other firms, which indicates that the firm has potential for profitability, causing demand for firm shares to increase so that it can increase the value of the company's shares. Then, in Tables 3 and 4, IO has a significant negative effect on firm performance based on ROA and Tobin's Q in the Philippines. This result indicates that the greater the IO, the worse the firm performance based on Tobin's Q. Based on a report from the Credit Suisse Research Institute (2010), 80\% of firms in the Philippines have institutional ownership in the family business. However, its existence does not control the firm directly but is limited by supervision, so that various policies made by the firm are purely from the management side. Therefore, this negative result indicates that institutional investors are not carrying out their role correctly, but they only rely on firm management to manage the firm.

Based on Tables 1, 2, 3, and 4, it can be seen that leverage (LEV) has a significant negative effect on firm performance based on ROA and Tobin's Q in Indonesia and the Philippines. This result indicates that the greater the LEV, the worse the firm performance based on ROA and Tobin's Q. A large LEV creates complexity for the firm in fulfilling its financial obligations to creditors. Then, the profits generated by the firm will be used to pay debts, interest to creditors so that firms with low leverage tend to have better performance.

Based on Tables 1 and 3, it can be seen that firm size (FS) has a significant positive effect on firm performance based on ROA in Indonesia and the Philippines. This result indicates that the bigger the FS, the better the firm performance based on ROA because large-size firms have easier access to external capital and better governance structures to be more effective than small-size firms.

Table 2 shows that FS has a negative effect on firm performance based on Tobin's Q in Indonesia. This result indicates that the bigger the 
FS, the worse the firm performance based on Tobin's Q because small-size firms tend to have less risk, making it more attractive for investors to invest and eventually raise the firm's stock price. Likewise, investors tend to avoid large-size firms because they have a high risk. Then, in Table 4, FS has an insignificant effect on firm performance based on Tobin's Q in the Philippines. This result indicates that FS does not affect firm performance based on Tobin's $Q$ because firm size, as measured by the natural logarithm of sales, does not reflect the actual sales value; thus, firm size cannot guarantee good firm performance.

\section{CONCLUSION}

This study results show that Board Size (BS) has no effect on firm performance based on ROA in Indonesia and the Philippines. However, BS has a significant negative effect on firm performance based on Tobin's Q in Indonesia and the Philippines. Board Meeting (BM) has a significant negative effect on firm performance based on ROA in Indonesia and a significant positive effect on firm performance based on ROA in the Philippines. However, BM has no effect on firm performance based on Tobin's Q in Indonesia and the Philippines. Institutional ownership has no effect on firm performance based on ROA in Indonesia. IO has a significant positive effect on firm performance based on Tobin's Q in Indonesia and a significant negative effect on firm performance based on ROA and Tobin's $\mathrm{Q}$ in the Philippines.

For the control variables, leverage has a significant negative effect on firm performance based on ROA and Tobin's Q in the Philippines. Furthermore, Firm Size (FS) has a significant positive effect on firm performance based on ROA in Indonesia and the Philippines, a significant negative effect on firm performance based on Tobin's Q in Indonesia, and no effect on firm performance based on Tobin's Q in the Philippines.

This study can be used as a reference for further research. This study has limitations, including the research period used and its focuses only on manufacturing sector companies listed on the Indonesia and Philippines Stock Exchange. For further research, the research period can be prolonged, use other countries as an object, and other variables not investigated in this study.

\section{REFERENCES}

Arora, A., Sharma, C. 2016. Corporate governance and firm performance in developing countries: evidence from India. Corporate Governance International Journal of Business in Society, 16(2):420-436.

Berkman, H., Zou, L., Shaofeng, G. 2009. Corporate governance, profit manipulation and stock return, Journal of International Business and Economics, 9: 132-145.

Haji, A.A., Mubaraq, S. 2015. The implications of the revised code of corporate governance on firm performance: a longitudinal examination of Malaysia listed companies. Journal of Accounting in Emerging Economies. 5(3): 350-380.

Klein, A. 1998. Firm performance and board committee structure. Journal of Law and Economics, 1: 275304.

Lee, S. 2009. Corporate governance and firm performance. PhD thesis. The University of Utah, Salt Lake City, Utah.

Letza, S., Sun, X., Kirkbride, J. 2004. Shareholding versus stakeholding: a critical review of corporate governance. Corporate governance: An international review, 12: 242-262.

Malik, M.S., Makhdoom, D.D. 2016. Does corporate governance beget firm performance in Fortune Global 500 companies?, Corporate Governance: The International Journal of Business in Society, 16(4): 747-764

Muchtar, S., Dadari, E. 2013, Pengaruh corporate governance terhadap kinerja perusahaan manufaktur yang terdaftar di Bursa Efek Indonesia. Jurnal Manajemen dan Pemasaran Jasa, 6: 109-132

Ratnadi, N.M.D., Ulupui I.G.K.A. 2016. Pengaruh Konsentrasi Kepemilikan dan Kompetensi Dewan Komisaris pada Konservatisma Akuntansi. Jurnal Akuntansi, 20(1): 1-15.

Shleifer, A., Vishny, R.W. 1997. A survey of corporate governance, Journal of Finance, 52(2): 727-783.

Sun, W., Stewart, J., \& Pollard, D., 2011. Corporate governance and the global financial crisis: International perspectives, Cambridge University Pres. 